\title{
Large Retropharyngeal Abscess Associated with Cervical Spine Tuberculosis
}

\author{
${ }^{1}$ Department of Neurosurgery, Narayana Medical College Hospital, \\ Chinthareddypalem, Nellore, Andhra Pradesh (India) \\ ${ }^{2}$ Department of Pathology, Narayana Medical College Hospital, \\ Chinthareddypalem, Nellore, Andhra Pradesh (India) \\ ${ }^{3}$ Department of Pulmonology, Narayana Medical College Hospital, \\ Chinthareddypalem, Nellore, Andhra Pradesh (India) \\ Indian J Neurosurg 2018;7:36-38
}

Amit Agrawal ${ }^{1} \quad$ Vissa Santhi ${ }^{2} \quad$ Gali Prakash Vignan Kumar ${ }^{3} \quad$ Yashwanth Sandeep $^{1}$

\begin{abstract}
Address for correspondence Amit Agrawal, MCh, Professor of Neurosurgery, Department of Neurosurgery, Narayana Medical College Hospital, Chinthareddypalem, Nellore 524003, Andhra Pradesh, India (e-mail: dramitagrawal@gmail.com).
\end{abstract}

\author{
Abstract \\ Keywords \\ - abscess \\ - tuberculosis \\ - retropharyngeal \\ abscesses \\ - Pott's spine
}

The authors report a case of a 25 -year-old man who presented with the history of neck pain and weakness of the right hand of 6-month duration. He had history of fever with evening rise in temperature, loss of weight, and cough. Radiologic investigations of the cervical spine showed collapse of the $C 5$ vertebral body and partial destruction of the $\mathrm{C} 4$ and $\mathrm{C} 6$ vertebral bodies with kyphotic deformity and a large retropharyngeal hyperintense collection. The patient underwent drainage of the abscess, and the histopathology was suggestive of tuberculosis. He was started on antitubercular treatment and doing well at follow-up.
Retropharyngeal abscesses are uncommon complication of spinal tuberculosis and can lead to potentially life-threatening airway compromise. ${ }^{1-5}$ A 25-year-old man presented with the history of neck pain radiating to left upper limb and weakness of the right hand, both of 6-month duration. He was not able to button and unbutton his clothes. He had history of fever for 6 months with evening rise in temperature and loss of weight $(\sim 5 \mathrm{~kg})$ in past 6 months. There was history of productive cough with sputum. There was no history of lower limb weakness or sensory disturbances or difficulty in swallowing. There was no history of bowel and bladder disturbances. He had history of injury to the neck while his brother caught him with his neck and it got twisted. His general and systemic examination was normal. There was tenderness or deformity over the cervical spine. Lateral radiograph of the cervical spine shows collapse of the $\mathrm{C} 5$ vertebral body and partial destruction of the $\mathrm{C} 4$ and $\mathrm{C} 6$ vertebral bodies with kyphotic deformity (-Fig. 1). Magnetic resonance imaging (MRI) of the cervical spine shows collapse of C5 vertebral body with kyphosis and a large retropharyngeal hyperintense collection ( - Fig. 2). Blood investigations were normal except raised erythrocyte sedimentation rate (ESR) (40 mm Hg). Chest X-ray was normal, and the sputum examination for acid-fast bacilli (AFB) and human immunodeficiency virus (HIV) tests were negative. The patient had a positive Mantoux test. Gastrografin study was normal. He underwent right anterior cervical approach and drainage of the abscess. Because of adhesions, implant could not be placed. Pus culture was sterile. Gram's stain showed no organism, only pus cells. Histopathologic examination of the granulation tissue showed glial tissue with granuloma-containing epithelioid cells, Langhans giant cells, and lymphocytes suggestive of tuberculosis (-Fig. 3). The patient was started on antitubercular treatment. Follow-up radiograph did not show worsening in kyphosis. He is doing well at follow-up.

Retropharyngeal abscess occurs either due to tubercular involvement of the lymph nodes in the retropharyngeal space ${ }^{6}$ or more commonly due to tubercular involvement of the cervical spine. ${ }^{7}$ The tubercular infection from the chest spreads hematogenously or via Batson's plexus to the vertebral bodies leading to the development of osteomyelitis, ${ }^{7-10}$ and as the infection continues to progress, it causes formation of the abscess that can rupture through the anterior longitudinal ligament and presenting as retropharyngeal abscess., ${ }^{7,910}$ The diagnosis of tubercular prevertebral abscess needs high index of suspicion, and when there is history of low-grade fever and weight $\operatorname{loss}^{1,7}$ and imaging shows destruction and collapse of vertebral bodies with intervertebral space involvement, received

November 9, 2016 accepted after revision

March 5, 2018

published online

May 15, 2018
Dol https://doi.org/

10.1055/s-0038-1649556. ISSN 2277-954X.
Copyright @2018 Neurological

Surgeons' Society of India
License terms

() (1) $\ominus \circledast$ 


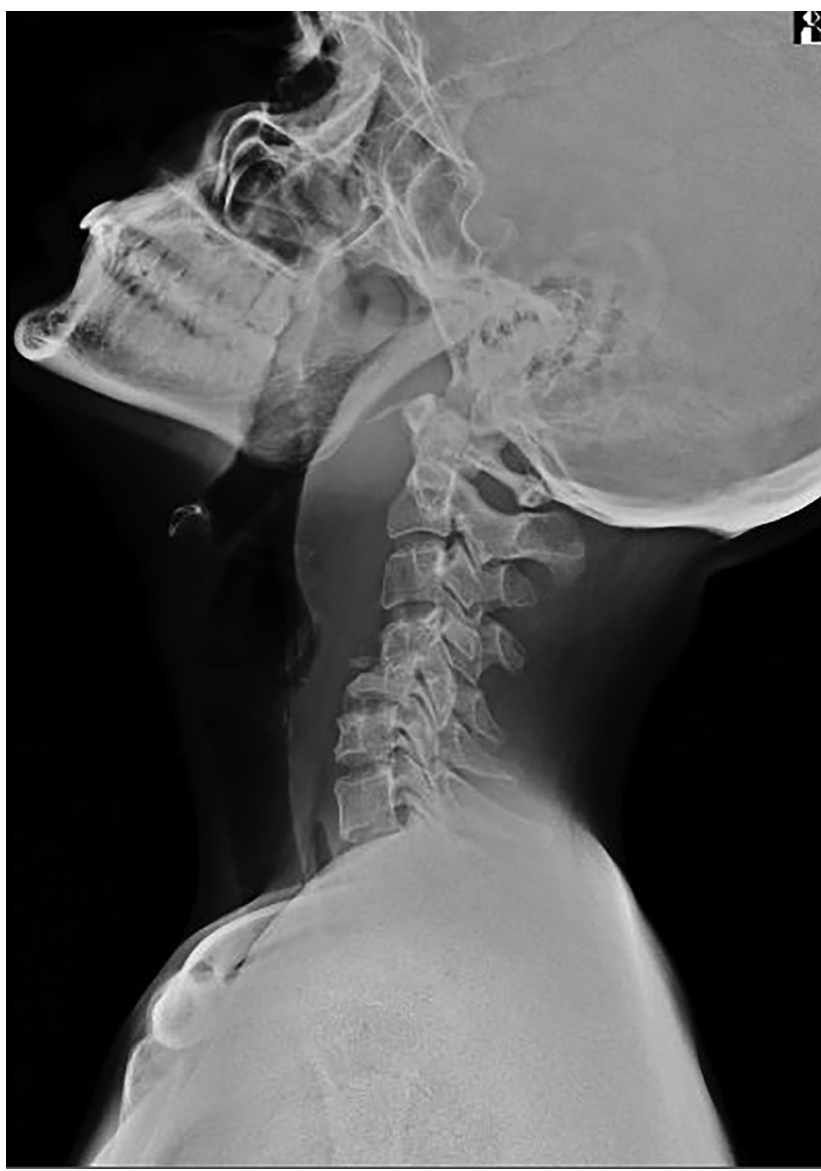

Fig. 1 Lateral radiograph of the cervical spine showing collapse of the $\mathrm{C} 5$ vertebral body and partial destruction of the $\mathrm{C} 4$ and $\mathrm{C} 6$ vertebral bodies with kyphotic deformity.

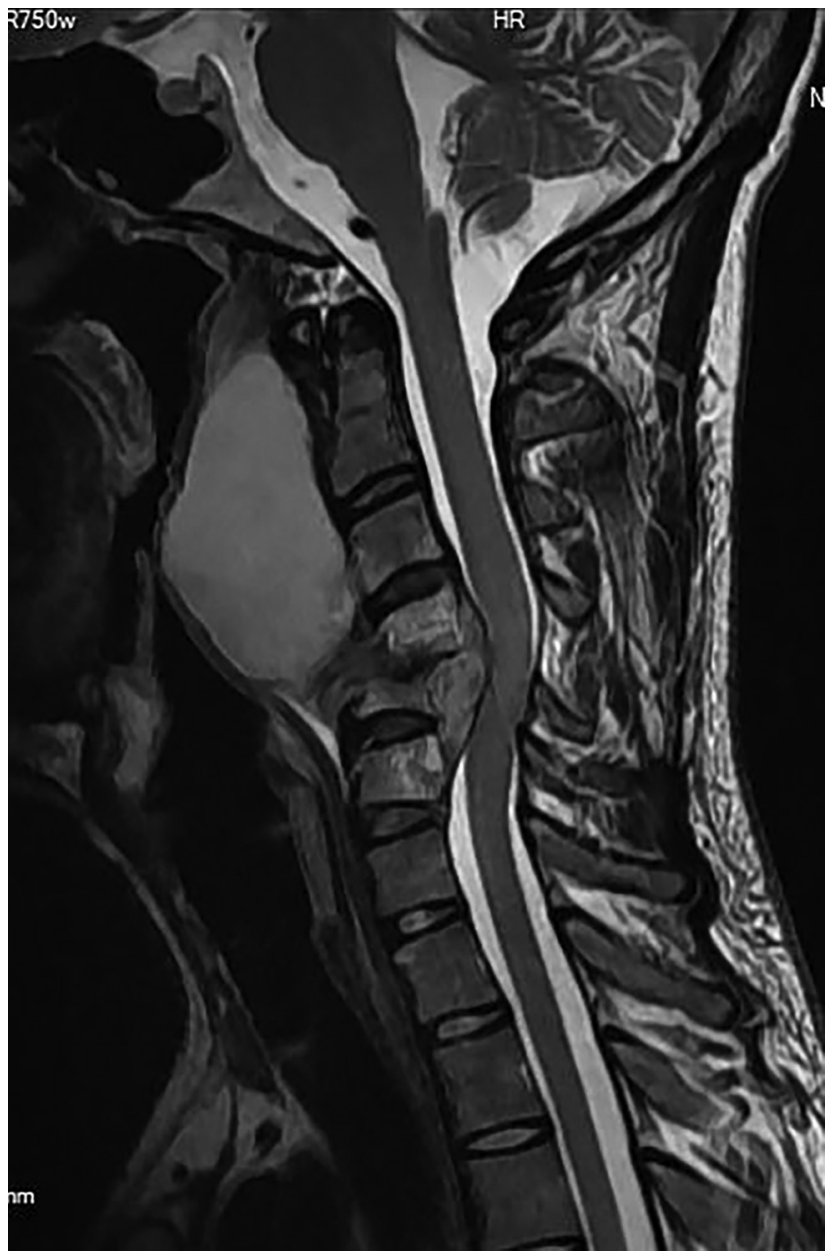

Fig. 2 MRI of the cervical spine showing collapse of C5 vertebral body with kyphosis and a large retropharyngeal collection.
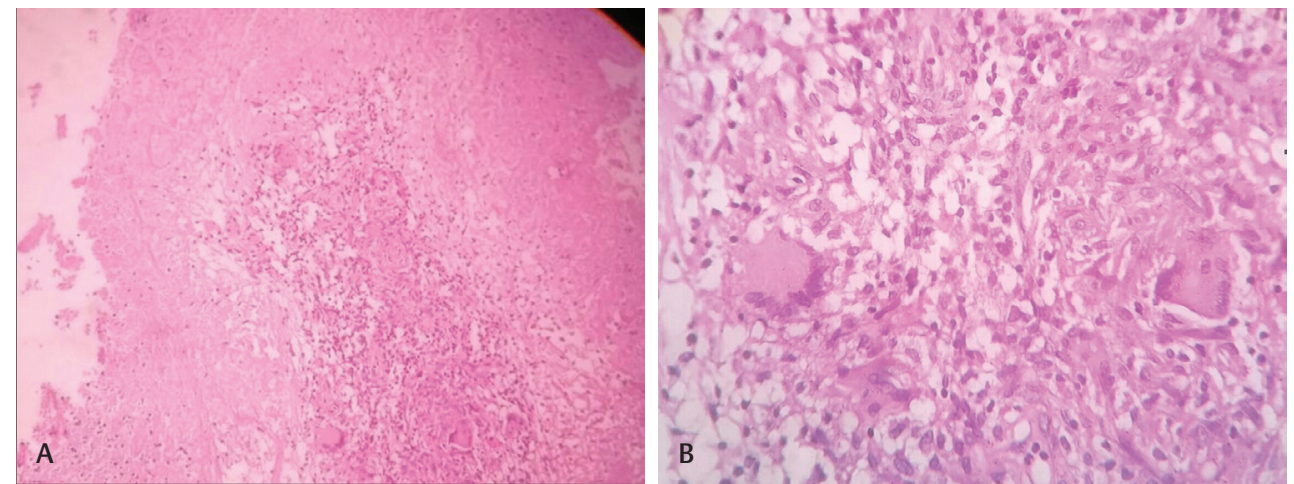

Fig. 3 (A) Glial tissue with granuloma-containing epithelioid cells, Langhans giant cells, and lymphocytes (H\&E × 100). (B) Granuloma-containing epithelioid cells, Langhans giant cells, and lymphocytes (H\&E ×400).

a diagnosis of tubercular origin should be suspected. ${ }^{7,9,11}$ If the abscess is large enough, it can cause drooling of saliva, dysphagia, hoarseness of voice, neck stiffness, torticollis, and airway compromise, which can lead to respiratory distress. ${ }^{9,12}$ Involvement of the vertebral bodies and neural structures can cause vertebral body collapse, extradural abscess, subluxation, and granulation tissue causing compression resulting in neurologic deficits. ${ }^{713}$ Imaging findings may include the increase in the size of the prevertebral shadow, presence of vertebral collapse, reduced vertebral height, narrowing of intervertebral disc space, vertebral body erosion, and loss of cervical lordosis. ${ }^{14-18}$ Gadolinium- enhanced MRI of the cervical spine further delineates details of the extent of neural structure involvement and adjacent soft tissue. ${ }^{2}$ Open surgical drainage is the treatment of choice for a large-size retropharyngeal abscess that is followed by antitubercular treatment. ${ }^{1,9,19}$ If left untreated, 
the progressively increasing retropharyngeal abscess can lead to airway obstruction; the abscess can rupture; spilling of the purulent material can cause aspiration and rarely mediastinitis ${ }^{9}$; there may be formation of epidural abscess, necrotizing fasciitis, jugular venous thrombosis, and sepsis; or it can cause erosion of the carotid artery. ${ }^{6}$

\section{References}

1 Singh J, Velankar H, Shinde D, Chordia N, Budhwani S. Retropharyngeal cold abscess without Pott's spine. S Afr J Surg 2012;50(4):137-139

2 Ogah OS, Owolabi MO, Akisanya CO. Cervical spine tuberculosis and retropharyngeal abscess in an adult Nigerian. Ann Trop Med Public Health 2012;5:587

3 Lafitte F, Martin-Duverneuil N, Brunet E, et al. Rhinopharynx et espaces profonds de la face: anatomie et applications à la pathologie. J Neuroradiol 1997;24(2):98-107

4 Melchor Díaz MA, Domingo Carrasco C, Monge Jodrá R, Mariño Espuelas J, Ontañon Martín M. [Tuberculous retropharyngeal abscess in an HIV patient. Report of a case] [in Spanish]. Acta Otorrinolaringol Esp 1993;44(6):467-470

5 Fernandez-Ponjoan E. Practical considerations from the study of one thousand patients with tuberculosis of the upper respiratory tract. Vida Nueva 1943;51:146-154

6 Marques PM, Spratley JEF, Leal LMM, Cardoso E, Santos M. Parapharyngeal abscess in children: five year retrospective study. Rev Bras Otorrinolaringol (Engl Ed) 2009;75:826-830

7 Saifi M, Kamal M, Singh MK. Tubercular prevertebral and epidural abscess presenting as stridor and dysphagia in an infant: a rare presentation of tuberculosis in infancy. Indian Journal of Case Reports 2016;2
8 Leibert E, Haralambou G. Spinal tuberculosis. In: Tuberculosis. Philadelphia, PA: Lippincott Williams \& Wilkins; 2004:565-577

9 Garg A, Wadhera R, Gulati SP, Kishore D, Singh J. Giant retropharyngeal abscess secondary to tubercular spondylitis. Indian J Tuberc 2009;56:225-228

10 Bhargava SK, Gupta S. Large retropharyngeal cold abscess in an adult with respiratory distress. J Laryngol Otol 1990;104(2):157-158

11 Janssens JP, de Haller R. Spinal tuberculosis in a developed country. A review of 26 cases with special emphasis on abscesses and neurologic complications. Clin Orthop Relat Res 1990;(257):67-75

12 Al Soub H. Retropharyngeal abscess associated with tuberculosis of the cervical spine. Tuber Lung Dis 1996;77(6):563-565

13 Gorse GJ, Pais MJ, Kusske JA, Cesario TC. Tuberculous spondylitis. A report of six cases and a review of the literature. Medicine (Baltimore) 1983;62(3):178-193

14 Moore SL, Rafii M. Imaging of musculoskeletal and spinal tuberculosis. Radiol Clin North Am 2001;39(2):329-342

15 Krishnan A, Patkar D, Patankar T, et al. Craniovertebral junction tuberculosis: a review of 29 cases. J Comput Assist Tomogr 2001;25(2):171-176

16 Bank DE, Krug SE. New approaches to upper airway disease. Emerg Med Clin North Am 1995;13(2):473-487

17 Duncan NO. Infections of the airway in children. In: Cummings CW, Flint PW, Haughey BH, et al, eds. Otolaryngology: Head \& Neck Surgery. 5th ed. Philadelphia, PA: Elsevier Mosby; 2010

18 Hoffman EB, Crosier JH, Cremin BJ. Imaging in children with spinal tuberculosis. A comparison of radiography, computed tomography and magnetic resonance imaging. J Bone Joint Surg Br 1993;75(2):233-239

19 Vieira F, Allen SM, Stocks RMS, Thompson JW. Deep neck infection. Otolaryngol Clin North Am 2008;41(3):459-483, vii 